\title{
OBITUARY
}

\section{PROFESSOR JULIUS NÉMETH}

One day late in 1956 as he was perusing some issues of our Society's Journal in the library, it crossed the mind of Julius Németh that in a long life rich in foreign contacts he had never been in touch with the Royal Asiatic Society. He then recalled that some time ago, it seemed, he had received a letter from the Society which, as it was his wont, he put on a neat little pile to join the company of similarly unopened mail. On his return home he retrieved the letter and read with pleasure that he had been elected an Honorary Fellow of the Society. The story was told to me by Professor Németh himself, over a delicious dinner of cold cuts prepared for us by Mrs. Németh, née Irene Sebestyén, the famous Finno-Ugrist linguist.

Gyula Németh - he used the first name Julius on his publications appearing in foreign languages - was born on 2 November 1890 in the small Hungarian town of Karcag located in a region settled in the 13th century by the immigrant Turkic Comans. To his death he kept a deep attachment to his birthplace, a feeling which manifested itself also in the conversational use of grammatical forms frowned upon by Hungarian purists. His interest in Turkish was awakened by some of the novels of the great Hungarian writer Jókai. He started learning the language at the age of 14 , and two years later he undertook his first journey to Turkey. Impressed by the young man's intelligence and enthusiasm, his teachers - Vámbéry, Goldziher, Munkácsi, Gombocz - sent him to Leipzig, Berlin, Kiel, but also to Russia to do field-work among its Turkic populations. In 1910 Németh worked in the Caucasus with the Kumyks and the Balkars; in 1913, in Ufa, he studied Chuvash. From the outset it was clear that Németh was to become a Turcologist and not merely a student of Ottoman. Plans for a journey to Siberia were dashed by the outbreak of World War I which, otherwise, has not marked a break in Németh's career. In 1918, at the early age of 28 , he became ordinarius in the chair once held by Vámbéry. In 1923 Németh was elected a corresponding member of the Hungarian Academy of Sciences and in 1932 he became a full member. With consummate skill which he used with an almost mischievous enjoyment, Németh weathered the stormy times of World War II and its aftermath which brought about radical changes in his country's political structure. From 1939 to 1949 he was secretary and later Chairman of the Academy's First Section (Language and Literature), and from 1950 to 1965 he was the director of its Linguistic Institute, which he built up into a very active, major scholarly institution unparalleled in its scope of activities anywhere west of the Soviet Union. In the difficult years of transition, 1947-1949, he was rector of the University of Budapest.

Neither honours, of which he has received many at home as well as abroad, 
nor positions of power have ever affected Németh's extremely modest lifestyle. Scholarship in its purest form was his sole passion. For him Turcology was first and foremost a means to clarify problems connected with the Hungarian past. In this he followed in the footsteps of Vámbery, but Németh's investigations are characterized by a rigorous method and minute attention to detail.

Németh's seminal work on Hungarian ethnogenesis ( $A$ honfoglaló magyarság kialakulása, Budapest, 1930) is a masterpiece of perennial value, his contribution to the study of the Comans, the Pechenegs, his work on Old Turkic runic inscriptions will be cited for years to come. He paid great attention to the study of Turkic ethnonyms, a field in which he was a pioneer. His brilliant study of "the people of the piebald horses", as well as his article on the prehistory of the Turks are marked by his vast erudition and common sense. Németh's etymological studies of Hungarian words such as tolmács "interpreter", tábor "camp", or of Mongol nökür "companion" cover a wide area and have ramifications ranging from China to the Slavic world. With the latter, Professor Németh had many other points of contact. He was an indefatigable explorer of the Turkic dialects of Bulgaria and used the knowledge thus gained to clarify many debated questions of comparative Turkic linguistics. He was 75 years of age when the fruit of nearly 40 years of labour, Die Türken von Vidin: Sprache, Folklore, Religion, appeared. Reviewing it for this Journal the late Sir Gerard Clauson called it "an admirable book". Luck as well as the flair of a real savant led him quite late in life to the identification and the subsequent publication of a trilingual glossary in Hungarian, Latin - and Alan! - a discovery of major importance for IndoIranian studies and for the history of this fascinating people.

A long life coupled with an iron self-discipline - Professor Németh lived according to a rigid daily timetable - allowed him to leave behind an oeuvre imposing in quality as well as quality. Our Society was well advised to add the name of this fine scholar to the distinguished list of its Honorary Fellows. He died on 14 December 1976 , in his 87 th year. $^{1}$

DENIS SINOR.

1 For a complete bibliography of Professor Németh cf. Acta Orientalia Academiae Scientiarum Hungaricae, XI, 1960,11-28, to be completed with the bibliography published on pp. 356-64 of Hungaro-Turcica: Studies in honour of Julius Németh, edited by Gy. Káldy-Nagy (Budapest, 1976). 